\title{
Identifying Elements of Gender References, Persuasive Techniques and Social Interaction Associated with Political Discourse: The Case of Hillary Clinton
}

\author{
Hanaa Ali AlQahtani ${ }^{1}$ \\ ${ }^{1}$ Department of Foreign Languages, Taif University, Taif, Saudi Arabia \\ Correspondence: Hanaa Ali AlQahtani, Department of Foreign Languages, Taif University, Taif, Saudi Arabia. \\ E-mail: qahtani_ha@yahoo.com
}

Received: June 25, 2019 Accepted: August 6, 2019 Online Published: September 11, 2019

doi:10.5539/ijel.v9n5p415 URL: https://doi.org/10.5539/ijel.v9n5p415

\begin{abstract}
Discourse is an important tool discussing social relations in the discursive patterns. A well-designed discourse can easily dominate people and can construct their perceptions. Therefore, discourse is critical in the political world when one uses it to communicate ideas and visions to the people. Therefore, the present study aims to identify the elements of gender references, persuasive techniques, and social interactions associated with political discourse of Hillary Clinton. The study has used the framework of conversation analysis for studying a total of three interviews and five debates of Hillary Clinton. The interviews and recording were extracted from YouTube and then transcribed and interpreted by converting them into text. The findings have revealed a significant use of persuasive techniques and social interaction in Clinton's political discourse. The results also imply that using affiliation strategy, candidates can manipulate people. The study concludes that this strategy is more effective in representing oneself as truthful as compared to conventional narratives.
\end{abstract}

Keywords: communication, political discourse, gender difference, social interaction, persuasive techniques

\section{Introduction}

Language is a highly considerable tool among political leaders to idealize their public image and to enhance their ideas (Lin, 2011). In other words, language is used by a politician to practice political power. Speeches, interviews, and panel discussions are the characteristics of political discourse, which consists of rhetorical features that are considered to be worthwhile from a sociolinguistic point of view (Roth, 2014). Concerning the communication between public and political leaders, speech is considered as a primary source in terms of its type, form, and the content which is always particular not like any university lecture neither and thus cannot be published in print media (Prifti, 2017). Language serves as an effective tool of persuasion. Thus, to attain the public's trust and favourable opinions, politicians have a proper linguistic approach for their speeches (Staugaite, 2014).

The use of speech is particularly evident in politics, where policy is often constructed using political language. Studies have identified that there are certain political advantages associated with language, which are categorized based on reality and honesty (Prifti, 2017; Totibadze, 2017). However, political speeches vary as political leaders need special linguistic and non-linguistic tools for speeches to achieve their political aims and objectives, specifically, to gain trust and votes from the public (Jensen, Jakobsen, \& Pichler, 2016; Prifti, 2017; Totibadze, 2017). Hillary Diane Rodham Clinton (DOB: October 26, 1947) is the first lady to be nominated for the presidency of the US major political party; named, Democratic.

Throughout her political discourse, she reflects as a political personality inclusive of both masculine and feminine roles termed as gender among politicians (Jensen, Jakobsen, \& Pichler, 2016). Similarly, an influential impact is observed of the social attitudes on the speaking styles of male and female and their attitudes towards society (Crespi, 2003; Merchant, 2012). For example, political speeches made by women in public are found to be assertive, autonomous, confrontational, aggressive, competitive, direct, task-oriented, dominating and interruptive, which, in general, seems to be appropriate. However, political speeches of men usually reflect a more dominant style of speaking (Holmes, 2006).

Referring to the case of Clinton, she often uses certain pronouns to reveal herself towards her supporters and opponents at the same time (Jensen, Jakobsen, \& Pichler, 2016). However, apart from the quality of the overall 
content of the speech, persuasive metaphors play a significant role in political speeches (Charteris-Black, 2014). By adopting a comprehensive approach towards her speeches, she was considered to bring experiences and awareness and praiseworthy policy goals to the table (Spring, 2016). In the United States of America, political speeches are formulated by the speechwriters and customized by the spin-doctors. The assessment of the political speeches is a necessity to ensure the content and concepts that can be completely understood by politicians for delivering it to the public. The linguistic type, rhetorical devices, ideologies, and strategies are all factors, which a politician should strive for to fulfil his aims.

Therefore, the study signifies that public political speeches should be based on persuasion, argumentation, and oratory skills as these aspects represent the overall political discourse. However, political speeches consist of subgenres such as a commemorative, inaugural address, speeches on party conventions, parliamentary speeches, State of the Union Address, slogans, speeches of ministers, press releases and press conferences, etc. Each of the subgenres reflects the form of social practice through language. However, genres offer not only normal framework but also influence other content features and reinforce the rhetorical development, which ultimately determines the linguistic choices. Therefore, the selection of the linguist and genres of the text and content development to reflect the pattern facilitates the understanding of the social and political truths and forces the speakers and politicians to speak within the accepted features, norms, and values. Within the same context, the study aims to identify the elements of gender references, persuasive techniques, and social interaction associated with Political Discourse. To assess this aim, the study focuses on the political use of First-Person Plural Pronoun (FPPP) and its self-affiliation.

\subsection{Study Objectives}

- To identify the elements of gender references, persuasive techniques, and social interaction associated with Political Discourse.

- To analyse the political use of FPPP.

- To study the case of Hilary Clinton case and political identity.

\section{Literature Review}

The literature review highlights the importance of critical discourse analysis in the form of political speeches. Thus, the review intends to identify the implicit patterns of the political discourse as they are structured with the specific goal in mind.

\subsection{Persuasive Techniques and Political Discourse}

Recently, Jensen (2016) has examined Clinton's campaign launch discourse to focus on the use of persuasive techniques. Through her discourse, she fought for three aspects i.e., from economy to the global issues to persuade the audience. She persuades the audience to overcome the economic issues faced by middle class and poor American in her first fight. She after initiating her first fight, stopped herself with a disclaimer, "[d]o I think it will be easy? Of course, not". Therefore, Clinton said that changing America's economic scenario is not going to be easy. However, by using persuasive techniques, she continued persuading people through her discourse after her negation.

In the second fight, she paid attention to strengthen America's family, and in the third fight, she paid attention to the position of America in the world. She used repetitive patterns to emphasize her point of view. At this point, Clinton, in her discourse, highlighted the global issues experienced by America. She stated, "[n]o other country on Earth is better positioned to thrive in the 21 st century. No other country is better equipped to meet traditional threats from countries like Russia, North Korea, and Iran - and to deal with the rise of new powers like China. No other country is better prepared to meet emerging threats from cyber-attacks, transnational terror networks like ISIS, and diseases that spread across oceans and continents". Focusing on these three statements with the same subject "no other country" underlined Clinton's point of view toward America.

The persuasive technique of the political discourse is also evident in the study of Sumanat (2016), which has examined the propaganda to persuade and manipulate the massive audience at the multitude level. The most significant source to use the propaganda seems to be political discourse such as debates, decision making, political speeches, and interviews, etc. It confirms the existence of propaganda techniques in political discourse. Thus, it is revealed that propaganda techniques do have an impact on the persuasion of the audience through political discourse. Accordingly, Altikriti (2016) has defined the use of language to establish a political business. This adds persuasive rhetoric, the utilization of euphemisms, and the use of language for spiralling the political emotions, along with a focus in the implicit meanings of words and for the exclusion of the undesirable realities. However, politicians use their discourse to persuade the audience on certain policies. Therefore, they intend to persuade the 
massive audience to eliminate difficulties to gain the support to fulfil their aims and programs.

Relevancy of gender in the political discourse has also been established by Roth (2014) who examined the importance of gender roles and gendered language in the political discourse. These gender variables are necessary to a significant level. Furthermore, the features of today's political discourse are heading towards the neutralized gender-based language. It is often created by the PR teams, rhetoric trainers, and image consultant that are associated with political personalities.

Glynos (2009) has examined the discourse-historical analysis (DHA) in terms of social interaction. The argument in DHA is to pay attention to the aims of social variables such as ethnicity, gender, and class. However, these social variables are not enough to define the impact of social context on discourse. The relationship between the discourse structure and social structure is moderate. Overall, DHA has highlighted the importance and need of social context to be included in the analytical procedure. It provides awareness about the relationship between social structures and social actors, which result in re-conceptualization of agency and subjectivity in the cognitivist term.

\section{Materials and Methods}

\subsection{Study Design}

In the present study, a qualitative research design is employed for identifying elements of gender references, persuasive techniques, and social interactions associated with political discourse. In this regard, the case of Hilary Clinton along with FPPP is considered. The selection of this research design is further derived from previous researches that have used the same study design and obtained cohesive results (Karpf et al., 2015; Ercan, Hendriks, \& Boswell, 2017).

\subsection{Study Framework}

The current study has reviewed different frameworks for identifying the relationship between gender and political discourse, persuasive technique and political discourse, and social interaction and political discourse. Based on the analysed factors and focus on the talk-in-interaction, the framework of Conversation Analysis (CA) is used for examining verbal interaction (Grebelsky-Lichtman, 2016; Stivers, 2015). The rationale behind the selection of CA is based on its established efficacy for understanding the way participants cooperate throughout their interaction (Brown \& Levinson, 1987; Schiffrin, 1994). Moreover, it also assists in describing the procedure, which allows conversing in a meaningful and orderly manner (Speer \& Stokoe, 2011). The multidisciplinary nature of CA enables its use across different disciplines; such as psychology, sociology, linguistics, and communication studies (Wilkinson \& Kitzinger, 2008).

\subsection{Study Procedure}

For conducting the study, video recordings and three interviews were carried out by the YouTube link through their site i.e., http://www.youtube.com and other news websites were also taken into consideration (Table 1). However, full recordings were retrieved from the news channels NBC News at http://www.c-span.org/. Deliberate selection of the audio and video material rather than printed text and audio recordings were made. After extracting the material, transcription and interpretation of the extracted material was involved in the next step based on the transcription of talk-shows and debates. Firstly, all the considered videos were converted into the texts. Later on, non-linguistic features were exempted such as hesitation markers and the paralinguistic features such as intonation, stress, pauses, and kinesics.

Table 1. Hillary Clinton's talk-shows

\begin{tabular}{ll}
\hline Talk-Show & Length (hours) \\
\hline Letterman (2000) & $0: 21: 50$ \\
Letterman (2003) & $0: 17: 59$ \\
DeGeneres (2008) & $0: 15: 17$ \\
\hline
\end{tabular}

\section{Results}

On the basis of three interviews and five debates of Hillary Clinton, the study had identified the elements; such as persuasive techniques, social interaction, and gender roles. These elements were associated with the political discourse of Hillary Clinton. The current study has investigated the political discourse of Hillary Clinton by using her interviews. The language used by her has helped to identify the social interaction in the discourse and revealed the power relations and ideology of the language. In Clintons' critical discourse, the researcher has found the use 
of language as a social practice, which constitutes forming social relations and social identities.

In Clinton's political discourse, the use of FPPP can be identified between Clinton and her male opponents. Particularly, the comparison between Clinton and Obama was seen in the study for two main reasons. Firstly, Clinton has more experiences with Obama as compared to other male opponents. Secondly, Obama was the only male who had defeated Clinton in the presidential election in 2008. The normalization of the frequencies as per 1000 words can be observed in Table 2 below.

Table 2. Frequency of the First Person Plural Pronoun (FPPP) in the discourse of Hillary Clinton and her male opponents

\begin{tabular}{|c|c|c|c|c|c|c|c|c|c|c|}
\hline Debate & & $\begin{array}{l}\text { Clinton- } \\
\text { Lazio } \\
2000\end{array}$ & & $\begin{array}{l}\text { Clinton- } \\
\text { Spencer } \\
2006\end{array}$ & & $\begin{array}{l}\text { Clinton- } \\
\text { Obama/Jan } \\
2008\end{array}$ & & $\begin{array}{l}\text { Clinton- } \\
\text { Obama/ } \\
\text { Feb } \\
2008\end{array}$ & & $\begin{array}{l}\text { Clinton- } \\
\text { Obama/ } \\
\text { Apr } \\
2008\end{array}$ \\
\hline S.no & $\mathrm{Cl}$ & $\mathrm{Laz}$ & $\mathrm{Cl}$ & Spn & $\mathrm{Cl}$ & $\mathrm{Ob}$ & $\mathrm{Cl}$ & $\mathrm{Ob}$ & $\mathrm{Cl}$ & $\mathrm{Ob}$ \\
\hline No. of FPPP & 101 & 72 & 141 & 65 & 32 & 44 & 136 & 165 & 192 & 171 \\
\hline Freq. & 25.48 & 17.65 & 36.14 & 17.92 & 13.38 & 18.45 & 28.21 & 25.16 & 42.86 & 32.22 \\
\hline
\end{tabular}

The study has revealed the constructive perspective and enlightened the pre-existing gender roles in America. The analysis of this study has highlighted Clinton's choice of language toward gender references. Speaking differently, the current study has not focused on gender differences specifically, but it is referring to the gender in her pronominal discourse. Clinton tends to express her political self collectively more than her male opponents. However, when the comparison is drawn at the individual level, the difference is less consistent. Clinton uses the FPPP considerably more frequently than do Lazio and Spencer (Clinton/Lazio: 25.48 vs. 17.65 and Clinton/Spencer: 36.14 vs. 17.92). With Obama, on the other hand, the differences are inconsistent between debates (Clinton/Obama: 13.38 vs. $18.45 ; 28.21$ vs. 25.16 and 42.86 vs. 32.22). The only debate in which Obama uses the FPPP more than Clinton is in the Jan/2008 debate.

Therefore, this difference supports the argument that Clinton was focused on addressing Obama rather than affiliating with him or with other groups. This again emphasizes the influence of this acrimonious debate on the distribution of the FPPP in Clinton's discourse. However, to compare the overall use of the FPPP in Clinton's and Obama's discourse in the three debates, a comparison between Clinton and Obama is drawn at the macro-level.

Table 3 shows the comparison of Clinton and her male opponents for the overall use of FPPP. The results have shown that the use of FPPP was relatively higher (30.79) as compared to other male opponents (23.55). This demonstrates that Clinton was more inclined to express her political self collectively.

Table 3. Comparison of overall FPPP frequency in the discourse of Hillary Clinton and her male opponents

\begin{tabular}{lll}
\hline Speaker & No. & Per 1000 Words \\
\hline Clinton & 602 & 30.79 \\
Male Opponents & 517 & 23.55 \\
\hline
\end{tabular}

The findings have revealed that Hillary Clinton seemed to use certain persuasive strategies while delivering her political speech. The researcher has found it more interesting to focus on the persuasive techniques of Clinton's discourse, which targets the expectations of the candidate instead of reason. Through the analysis of the data, the types of persuasion techniques discovered were ethos, pathos, and logos. Ethos is a persuasive technique, which was used by Hillary Clinton to persuade her followers by displaying her good image and her credibility as the presidential candidate of America. Pathos is another strategy used by Hillary Clinton to control the emotions of the audience. Logos is another and last persuasive technique used by Hillary Clinton, which she initiated in her logical arguments, talked about the facts, promises, and more. All these types of persuasion techniques used by Hillary Clinton in her speech were conducted in New York City.

Clinton's discourse, arguably, may be more oriented towards positive politeness than that of her male opponents. Clinton uses the FPPP to show solidarity with and an interest in the addressee(s) by sharing common ground with them, and she does this more than her male opponents. In this manner, Clinton's style in the analysed data can be described as feminine. Thus, it is characterized by cooperative ways of speaking, compared to the men's more competitive style. 
The FPPP serves more functions than just positive politeness. The multi-listener context in debates, for example, allows Clinton to use the FPPP towards strategies that function beyond positive politeness; that is, strategies that save her negative face in FTAs. In other situations, Clinton uses the FPPP in the impoliteness scope to threaten her opponent's face by excluding him from the national or partisan collective. Therefore, this high frequency of FPPP use in Clinton's debates should not lead to conclusions that Clinton's style is more positively polite than that of her male opponents, given that the FPPP serves many different strategies beyond positive-politeness.

\section{Discussion and Conclusion}

The language used by Hilary Clinton in her political discourse, interviews, and debates had revealed social interaction, persuasive techniques, and gender roles. Similar to the present study, Sánchez (2017) found out persuasive techniques in Clinton's political discourse. Clinton intentionally wanted her opponent to know i.e., her political background and experience as the First Lady Senator of USA. Moreover, in one of her discourse, she has used a personal tone and language within the political context by saying, "I am going to do what I know works." This was observed to be highly persuasive in terms of her foundation of power.

Clinton once again had used persuasive techniques in the form of repetitive patterns of same sentences to emphasize her point of view towards the audience. It leads to a high level of hope among people of America (Jensen, Jakobsen, \& Pichler, 2016). Despite being a presidential candidate, she broke the highest yet hardest glass ceiling to make her voters realize that they both are same. This strategy has persuaded her voters to believe in her (Abercrombie, 2014). Moreover, Clinton's use of language revealed her social inclusion, which helped her to be persuasive. Trump was reflected to be aggressive in her political discourse, which reflects a negative moral by creating a sense of fear among the audience (Sánchez, 2017). Similarly, Clinton has used another form of rhetoric such as repetition, flatter, and seduction, which were categorized as her persuasive techniques (Jensen, Jakobsen, \& Pichler, 2016).

Similar to the present study, Jensen, Jakobsen and Pichler (2016) have shed light on the social interaction found in Clinton's political discourse. Clinton was habitual of using certain language, which demonstrates Clinton's love for people. She wanted to call the attention of the audience by letting them know that she can take care of the people of the country. She has also indicated that she does not judge people by their social status and race. In addition, the concept of others was generated by Clinton in her campaign launch, which identified her with low social interaction level with the audience. Majority of the groups in her campaign launch were poor, belonged to different colour, race, and disabled people. Clinton had distanced herself from these groups as if she did not know them (Tope et al., 2014). Hillary Clinton was known to be a successful female political person who had influenced the world with her personal experience, multiple social identities, her relationship with people, and her speeches. This has highlighted her to be a socially active political candidate in America (Chen, 2018). However, Tope et al. (2014) have revealed the stereotypical representation emphasizing the poor social status through Clinton's political speeches.

Madsen (2018) disagrees with the current study findings by claiming that voters seem to be less persuasive by the female political candidates as compared to male candidates. According to the study, female candidates can be affected by the recognition of less trust, whereas male candidates face more adverse effects when perceived with less expertise. However, perceived expertise seems to be easy to repair as compared to the trustworthiness. On the contrary, Clinton has highlighted the violation of human rights that is the root cause of racism, oppression, patriarchy, supremacy, and capitalism faced by women on the global level (Matos, 2012). Moreover, Clinton's failed political campaign was a reason for using gender card in her political discourse and interviews. Her gender strategy, the campaign message, and false utilization of media have led her to the failure. However, during the acknowledgment of gendered strategies, the gendered media bias seemed to be less prevalent as compared to the analysis of Clinton's campaigns (Larywon, 2011).

When it comes to discuss children and family minority groups, Clinton's performance becomes feminine based on the Nurturant Parent Model. This result in benefits from the rhetoric effect of pathos. However, when addressing immigrant issues, economy and world problems, Clinton's discourse become masculine due to the extensive use of ethos. Clinton demands certain behaviours and asks for the trust of American people in her. However, Jensen, Jakobsen and Pichler (2016) have contradicted with the findings of the present study by claiming that all persuasive and social aspects of Clinton's discourse were not identified, such as volume, voice quality, gestures, pitch visual aids, and race. Moreover, Trump is a prominent political leader, and present President of America is not being identified in terms of persuasion, social interaction, and gender preferences in the present study.

At this juncture, Clinton is considered a skilled orator who can use the most influential rhetoric features in political speeches. Reflecting upon the three interviews and five debates of Hillary Clinton, the study has found influential 
elements such as persuasive techniques, social interaction, and gender reference in her political discourse. Therefore, Clintons' use of language in her discourse cued her as a representative of persuasive techniques, gender references, and social interaction. Clinton used gender identity in many of her discourses, but the present study has identified persuasive techniques and social interaction in Clinton's discourse, but no gender stereotype can be observed. Therefore, further studies are recommended to identify gender stereotype in the political discourses of renowned politicians.

Moreover, a comparative study can be carried out to figure out similarities and dissimilarities in the speeches of a male and female candidate. The study also directs the future researchers emphasizing close examination of the other non-verbal and verbal cues that reveal the credibility of a candidate. Therefore, a comparative study between Clinton and other political leaders should be undertaken that can examine credibility and likability among voters. Moreover, the present study can be beneficial for the researchers investigating Clinton's rhetoric and its outcomes related to senatorial and presidential elections. The study by focusing on Clinton's political discourses also has privileged female political leaders of different parts of the world.

\section{Acknowledgment}

The author is very thankful to all the associated personnel in any reference that contributed to/for this research. This research holds no conflict of interest and is not funded through any source.

\section{References}

Abercrombie, K. (2014). Hillary Clinton's 2008 Concession Speech: Rhetorical Feminist and Ideological Criticism. Retrieved from https://www.csus.edu/acaf/ge/writing\%20across\%20the\%20curriculum/assets/abercrombie-kelly-clinton-hil lary-concessoin.pdf

Altikriti, S. (2016). Persuasive speech acts in Barack Obama's inaugural speeches $(2009,2013)$ and the last State of the Union Address (2016). International Journal of Linguistics, 8(2), 47-66. https://doi.org/10.5296/ijl.v8i2.9274

Brown, P., \& Levinson, S. C. (1987). Politeness: Some universals in language use. Cambridge: Cambridge University Press. https://doi.org/10.1017/CBO9780511813085

Charteris-Black, J. (2014). Analyzing political speeches: Rhetoric, discourse, and metaphor. Basingstoke: Palgrave Macmillan. https://doi.org/10.1007/978-1-137-36833-1

Chen, Y. (2018). On Rhetorical Functions of Narratives in Hillary Clinton's Speeches. International Journal of Language and Linguistics, 6(4), 134-139. https://doi.org/10.11648/j.ijl1.20180604.15

Crespi, I. (2003). Gender socialization within the family: A study on adolescents and their parents in Great Britain. Department of Sociology Catholic University of Milan.

Ercan, S. A., Hendriks, C. M., \& Boswell, J. (2017). Studying public deliberation after the systemic turn: the crucial role for interpretive research. Policy \& Politics, 45(2), 195-212. https://doi.org/10.1332/030557315X14502713105886

Glynos, J., Howarth, D., Norval, A., \& Speed, E. (2009). Discourse analysis: Varieties and methods.

Grebelsky-Lichtman, T. (2016). The role of verbal and nonverbal behavior in televised political debates. Journal of Political Marketing, 15(4), 362-387. https://doi.org/10.1080/15377857.2014.959688

Holmes, J. (2006). Gendered Talk at Work: Constructing Gender Identity through Workplace Discourse. Oxford: Blackwell. https://doi.org/10.1002/9780470754863

Jensen, I., Jakobsen, I. K., \& Pichler, L. H. (2016). A Critical Discourse Study of Hillary Clinton's 2015/2016.

Karpf, D., Kreiss, D., Nielsen, R. K., \& Powers, M. (2015). Qualitative Political Communication| Introduction The role of qualitative methods in political communication Research: Past, present, and future. International Journal of Communication, 9, 19.

Larywon, M. R. (2011). Hillary Clinton's Turbulent Run for The White House: Media Bias or Campaign Gaffe?

Lin, C. W. (2011). The Study of Political Language: A Brief Overview of Recent Research.

Madsen, J. K. (2018). Voter Reasoning Bias When Evaluating Statements from Female and Male Political Candidates. Politics \& Gender, 1-26. https://doi.org/10.1017/S1743923X18000302

Matos, J. (2012). Women's rights in public address: A feminist rhetorical critique. Retrieved from http://www.calstatela.edu/sites/default/files/users/u2276/colloquy_2015_matos.pdf 
Merchant, K. (2012). How Men and Women Differ: Gender Differences in Communication Styles, Influence Tactics, and Leadership Styles (p. 513). CMC Senior Theses. Retrieved from $\mathrm{http}: / /$ scholarship.claremont.edu/cmc_theses/513

Presidential Campaign Discourses. (2016). A Critical Discourse Study of Hillary Clinton's 2015/2016. Retrieved from https://projekter.aau.dk/projekter/files/239472135/Master_s_Thesis.pdf

Prifti, M. (2017). Characteristics of Political Discourse in Albania. European Journal of Research in Social Sciences, 5(4).

Roth, S. S. (2014). Power, politics, and gender-related epistemic modality in interview discourse.

Sánchez, F. (2017). Political communication and virality in the US presidential campaign: A CDA analysis of the 2016 US presidential candidates' discourses and performances in late night shows.

Schiffrin, D. (1994). Approaches to discourse. Oxford: Blackwell.

Speer, S. A., \& Stokoe, E. (Eds.). (2011). Conversation and gender. Cambridge University Press. https://doi.org/10.1017/CBO9780511781032

Spring, C. A. (2016). Crafting Rhetorics of Trust: Hillary Rodham Clinton and her Appeals to the American People.

Staugaite, I. (2014). Linguistic Realization of Rhetorical Strategies in Barack Obama and Dalia Grybauskaite's Political Speeches. Lithuanian University of Educational Sciences: Vilnius.

Stivers, T. (2015). Coding social interaction: A heretical approach in conversation analysis? Research on Language and Social Interaction, 48(1), 1-19. https://doi.org/10.1080/08351813.2015.993837

Sumanat, W., \& Dispanya, E. O. (2016). Propaganda Techniques in the Political Discourses of Aung San Suu Kyi.

Tope, D., Pickett, J. T., Cobb, R. J., \& Dirlam, J. (2014). Othering Obama: Racial Attitudes and Dubious Beliefs about the Nation's First Black President. Sociological Perspectives, 57(4), 450-469. https://doi.org/10.1177/0731121414536140

Totibadze, S. (2017). Most Frequently Used Gendered Metaphors in British Political Discourse (Based on the Discourse Analysis of Four British Prime Ministers. Master's thesis.

Wilkinson, S., \& Kitzinger, C. (2008). Using conversation analysis in feminist and critical research. Social and Personality Psychology Compass, 2(2), 555-573. https://doi.org/10.1111/j.1751-9004.2007.00049.x

\section{Copyrights}

Copyright for this article is retained by the author, with first publication rights granted to the journal.

This is an open-access article distributed under the terms and conditions of the Creative Commons Attribution license (http://creativecommons.org/licenses/by/4.0/). 